\title{
COMPARISON OF VISEGRAD FOUR FROM THE VIEWPOINT OF OPINIONS ON IMMIGRANTS ${ }^{1}$
}

\author{
Miroslava Bozogáňová ${ }^{1}$, Tatiana Lorincová ${ }^{2}$, Monika Magdová ${ }^{3}$, \\ \& Marianna Berinšterová ${ }^{3}$ \\ ${ }^{I}$ The Institute of Social Sciences, Centre of Social and Psychological Sciences of Slovak Academy \\ of Sciences (Slovakia) \\ ${ }^{2}$ The Department of Managerial Psychology, Faculty of Management, The University of Presov \\ (Slovakia) \\ ${ }^{3}$ Institute of Pedagogy and Psychology, Faculty of Humanities and Natural Science, \\ The University of Presov (Slovakia)
}

\begin{abstract}
The goal of this paper is to analyze the opinions of Visegrad Four (V4) on immigrants and offer an overview of the basic information acquired from reliable data. According to Eurobarometer 88.2 (2017), immigrants are: people born outside of the European Union, who left their home country and currently legally reside in country. The research set consisted of: a) 1080 respondents from the Slovak Republic - $43.1 \%$ men and $56.9 \%$ women, aged $15-93 \quad(\mathrm{M}=49.45, \mathrm{SD}=16.83)$; b) Czech Republic - 1027 respondents - 40.5\% men and 59.5\% women, aged $15-91(\mathrm{M}=47.08$; $\mathrm{SD}=16.41)$; c) Hungary -1038 respondents $-42.3 \%$ men and $57.7 \%$ women, aged $15-99(\mathrm{M}=51.69$; $\mathrm{SD}=16.73)$; and d) Poland -1037 respondents $-39.7 \%$ men and $60.3 \%$ women, aged $15-99(\mathrm{M}=48.94$; $\mathrm{SD}=17.89$ ). For these purposes we used data from module Integration of immigrants in the European Union Eurobarometer 88.2 (2017), which were newly introduced. Data collection took place in October 2017 in the form of a face-to-face interview in the form of a multi-level probabilistic selection.

We have used items from Eurobarometer 88.2 (2017) to measure the opinions. The items were subjected to principal axis factoring to assess the dimensionality of the data. We have named the first factor as "Immigrants as help" (Cronbachs'alpha $=0.845$ ) and the second factor as "Immigrants as a burden" $($ Cronbachs'alpha $=0.762)$. We have found that the Slovak respondents, most of V4 (Slovakia, Czech Republic, Hungary and Poland) agree with the negative statements about immigrants and at the lowest rate (except Hungary) agree with the positive statements about immigrants.

The contribution of the paper is an overview of the opinions of V4 on a representative sample, thanks to which it is easier to understand the mood in the countries on this always-topical topic. The paper offers space for reflections and research topics within V4.
\end{abstract}

Keywords: Immigrants, Visegrad Four, opinions, eurobarometer.

\section{Introduction}

Residents of European countries have different experiences with migration, leading to differences on country level. The comparability of the obtained data with the secondary data of other European countries (ESS, ISSP, IVO, young - Kucharczyk et al., 2017) will be beneficial, considering the effect of the country. Information about attitudes toward migrants among Slovak respondents are currently only partial (ESS, ISSP) - e.g., in terms of the limited number of migrants with admission to the country, the Swedes appear to be the most tolerant and the Czech Republic the least (Boelhouwer, Kraaykamp, \& Stoop, 2016). As individual countries differ in migration (e.g. 2017 in the SR - 29 asylum seekers vs. Germany - 186,644), we are interested in where the Slovak is placed. In our research we focused on Visegrad Four countries (the Czech Republic, Hungary, Poland and Slovakia), that are members of the European Union (EU) and NATO

Slovakia is not one of the traditional final destinations for migrants. It is a culturally homogeneous country, which was not affected by the dramatic increase of migration during the twentieth century. Until recently, Slovakia was almost exclusively a country of emigrants, in other words, a country, whose residents used to emigrate abroad for various reasons (IOM, 2019).

\footnotetext{
${ }^{1}$ This research was supported by a grant VEGA 2/0068/19: Attitudes towards Migrants in the Socio-psychological Context.
} 
According to the results of research on public attitudes towards migration of the International Organization for Migration (2019), the Slovak population has relatively little personal experience and knowledge of migrants. It typically creates its opinions based on media reports. Residents are afraid that Slovakia has a high number of migrants who take jobs, spread diseases, and are an economic burden for the budget (Vašečka, 2009). In 2019, out of 216 asylum seekers, nine were granted, eighteen were granted subsidiary protection and seven were granted citizenship. Prep comparison - in 2018 there were 178 asylum seekers in Slovakia, 1690 in the Czech Republic, 4110 in Poland and 671 in Hungary (V4 report, 2019).

Scientists from different disciplines are keen to examine these anti-immigration attitudes. Research in this field demonstrates that attitudes towards migrants are partially group-specific and dependent on cultural similarity of the migrants (Ford, 2011), educational level and work skills (Helbling \& Kriesi, 2014), language and skin color (Hopkins, 2015), national origin (Hainmueller \& Hangartner, 2013), religion and economic contribution (Bansak et al, 2016). The nature of migration also reflects in the willingness of the population to accept the migrants. If migration is perceived as voluntary, it is associated with a lower level of support and more anger, whereas for involuntary migration it is vice-versa (Verkuyten et al., 2018). In examining attitudes towards migrants, the most common explanatory socio-psychological constructs are the integrated threat theory (Nsom \& Croucher, 2017), the theory of social dominance (Roccato \& Ricolfi, 2005; Ho et al., 2015), social distance (Heath et al., 2014) and the contact theory - direct contact between groups increases attractiveness because it makes it difficult for a group to accept typical negative stereotypes (Himmelroos \& Leino, 2016). According to this theory, direct contact between groups eliminates the maintenance of typically negative stereotypes (Allport, 1954). Through contact, individuals are exposed to new information about another group. This information helps to understand the concerns and interests of the second group, while developing affective ties that reduce feelings of threat and refute negative stereotypes about members of the second group. Studies on the positive impact of contacts in relation to immigrants bring ambiguous results. While some of these assumptions were confirmed (Schlueter, \& Scheepers, 2010; Ellison, Shin, \& Leal, 2011), others did not confirm the assumed relationship (Gravelle, 2016). Karreth, Singh and Stojek (2006) have found that contact with immigrants can lead to their perception as a cultural threat, which may ultimately support overall anti-immigration sentiment.

Since the migration issue has gained a lot of attention recently, it is inevitable to analyze public opinions. The findings by Heath and Richards (2016) suggest some shift in the society. They analyzed over 40000 survey responses in the European Social Survey, which were obtained in 2002/2003 (ESS Round 1) and 2014/2015 (ESS Round 7). The results show that out of 19 countries that participated in the 2002/2003 survey, only citizens from the Czech Republic and Austria expressed the opinion that migration makes their country a worse place to live. In both rounds, Swedes, Danes and Finns expressed the most positive attitudes towards migration and migrants, while the Czechs, Hungarians and Portuguese felt the most negative attitudes on this issue.

From this short theoretical overview, it is clear that the opinions on immigrants are influenced by many factors. Comprehensive study of this issue is needed to understand the whole process.

\section{Goal of the survey}

The goal of this paper is to analyze the opinions of the Visegrad Four (V4) on immigrants and offer an overview of the basic information acquired from reliable data. According to Eurobarometer 88.2 (2017), immigrants are: people born outside of the European Union, who left their home country and currently legally reside in country.

\section{Methods}

\subsection{Study sample and procedure}

Eurobarometer surveys monitor the evolution of public opinion in all EU Member States. The aim is to assess EU citizens' awareness of and support for the European Union's activities. For these purposes we used data from module Integration of immigrants in the European Union Eurobarometer 88.2 (2017), which was newly introduced. The full text of the module is freely available on the pages of said survey.

The first research set consisted of 1080 respondents (Eurobarometer 88.2, 2017) from the Slovak Republic $-43.1 \%$ men, aged 15 - $93(\mathrm{M}=49.45, \mathrm{SD}=16.83)$, Czech Republic -1027 respondents $(40.5 \%$ men), aged 15 - $91(\mathrm{M}=47.08 ; \mathrm{SD}=16.41)$, Hungary -1038 respondents $(42.3 \% \mathrm{men})$, aged $15-99$ $(M=51.69 ; \mathrm{SD}=16.73)$ and Poland -1037 respondents $(39.7 \%$ men $)$, aged $15-99(\mathrm{M}=48.94 ; \mathrm{SD}=17.89)$. Data collection took place in October 2017 in the form of a face-to-face interview as part of Eurobarometer 88.2 (2017) in the form of a multi-level probabilistic selection. 


\subsection{Measures}

We used items from Eurobarometer 88.2 (2017) to measure the opinions. The opinions of the migrants were measured using a 7 - item scale ranging from 1 - strongly agree - 4 - strongly disagree, we have reversed the polarity of the items for easier data interpretation - higher score = stronger approval with the statements. The items were subjected to principal axis factoring to assess the dimensionality of the data (Kaiser-Meyer-Olkin $=.834$; Bartlett's Test of Sphericity $X^{2}=8792,561 ; \mathrm{df}=21 ; \mathrm{p}<.01$ ). We have named the first factor as "Immigrants as help,, (Cronbachs'alpha $=0.845)$ and the second factor as “Immigrants as a burden” (Cronbachs'alpha =0.762).

Table 1. Rotated factor matrix - opinions of the immigrants.

\begin{tabular}{lcc}
\hline \multicolumn{1}{c}{ Impact of immigrants on society } & \multicolumn{2}{c}{ Factor } \\
& Immigrants as help & Immigrants as burden \\
\hline - positive for national economy & .762 & .758 \\
- burden on welfare system & & .576 \\
- take jobs away from workers & .641 & \\
- help to fill jobs & .787 & .713 \\
- new ideas and innovation in (country) & .760 & \\
- enrich (national) cultural life & & \\
- worsen crime problems in (country) & & \\
\hline Extraction Method: Principal Axis Factoring. &
\end{tabular}

\subsection{Statistical analysis}

The information collected in the course of the survey was processed using descriptive statistics available in the SPSS 21.0 program.

\section{Results}

First of all, we would like to point out the opinions on immigrants of the Slovak Republic in the context of the V4 countries (Czech Republic, Hungary, Poland). In the "Immigrants as help" factor, the respondents could achieve the highest score of 16 and in the "Immigrants as a burden" factor the highest score was 12 . We have used weighted data to compare the countries.

Figure 1. Attitudes towards immigrants in V4 (burden, help)- mean scores.

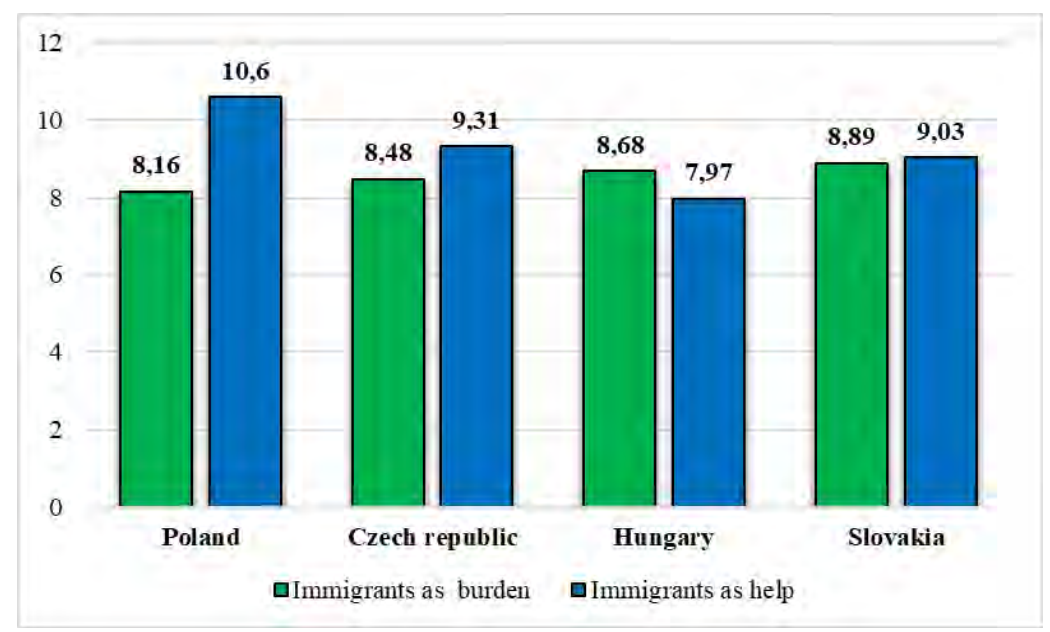

In Figure 1 we can see that in the V4 group, Slovakia agrees the most with statements denoting immigrants as a burden $(\mathrm{M}=8.89 ; \mathrm{SD}=2.14)$. Poland has the lowest approval rate in this factor $(\mathrm{M}=8.16 ; \mathrm{SD}=2.13)$ among the V4 countries. The one-way ANOVA analysis shows that there are statistically significant differences among the countries in their opinions on immigrants - "immigrants as a burden" - there was a significant effect for a country on the negative opinions on immigrants at the $\mathrm{p}<.01$ level for four countries $(\mathrm{F}(3,3636)=16.746 ; \mathrm{p}<.01)$. Post hoc comparisons using the Tukey HSD test indicated that the mean scores were significantly different in opinions on immigrants ("immigrants as a burden") between Poland and other countries (Poland has the lowest negative attitudes among countries); Slovakia and Czech Republic. 
Furthermore, we have found that there are statistically significant differences among countries in their opinions on immigrants - "immigrants as help" - there was a significant effect for a country on the positive opinions on immigrants at the $p<.01$ level for four countries $(F(3,3362)=116.904 ; p<.01)$. Post hoc comparisons using the Tukey HSD test indicated that the mean score was not significantly different $(\mathrm{p}>.05)$ between Slovakia and the Czech Republic. In other countries, there were significant differences $(p<.01)$ in opinions on immigrants ("immigrants as help").

We have found that the Slovak respondents, most of V4 (Slovakia, Czech Republic, Hungary and Poland) agree with the negative statements about immigrants and at the lowest rate (except Hungary) agree with the positive statements about immigrants.

Figure 2. Immigrants staying i/legally-opinions.

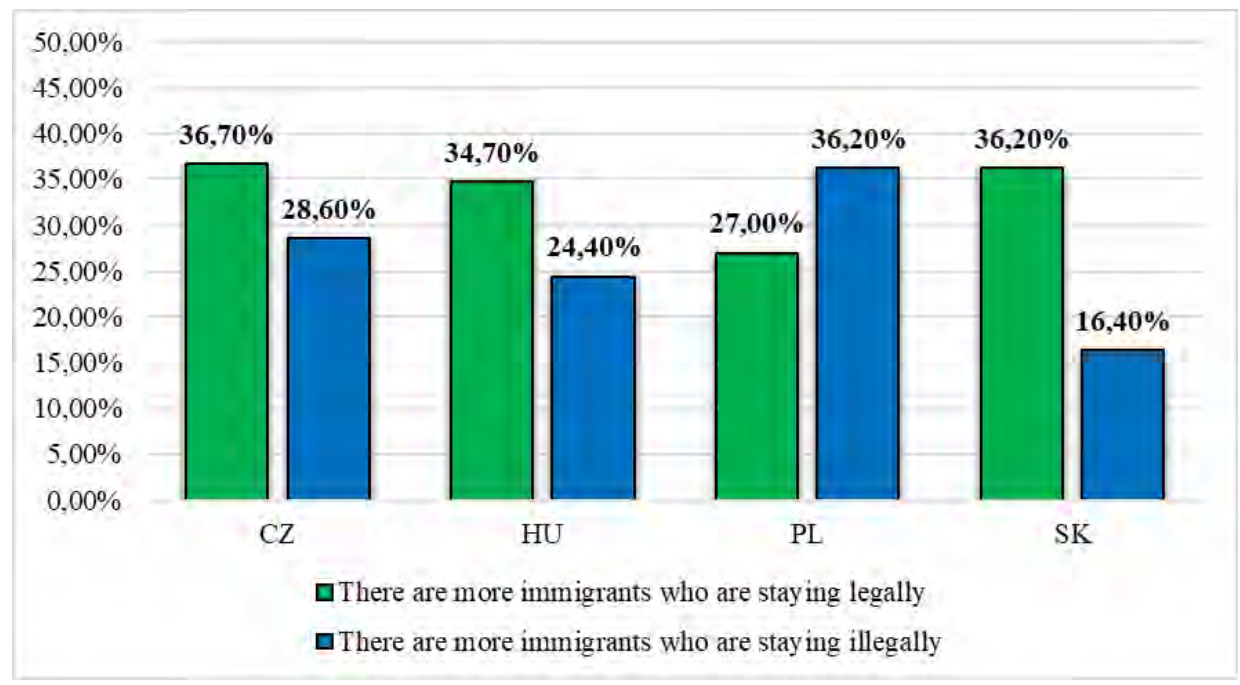

Interestingly, the respondents of Poland think that up to $36.2 \%$ of immigrants stay illegally in the country. Nevertheless, in other indicators of attitudes towards immigrants, they appear to be most positive. $16.4 \%$ of Slovaks think that more immigrants stay in Slovakia illegally and their attitude towards them is negative compared to other V4 countries.

\section{Discussion and conclusion}

The goal of this paper was to analyze the opinions of the V4 countries on immigration. Slovak, Czech Republic and Hungary have rather negative opinion on immigration and immigrants when compared to Poland. Similar to the findings of Heath and Richards (2016) based on data from the first and seventh round of the European Social Survey, Hungary and the Czech Republic are also among countries with rather negative opinions on immigration. In our research we have found that these countries agree the most with the item "immigrants as a burden" of all the countries of V4. Slovakia joins them. We consider this result as interesting, since compared to the other countries of the European Union, the Slovak Republic has low levels of foreigners in its population (IOM, 2019). Unlike Hungary, Slovakia does not have a negative experience with immigrants (immigrants' oat the Budapest Keleti Train Station in 2015).

Polish people have the most positive opinions on immigrants of the V4 countries. We could also explain the more positive attitudes of Poles using contact theory. Of the V4 countries, Poles have the highest number of asylum applications, and similarly, they have the most experience with immigrants in the country. Through contact, individuals are exposed to new information about another group. This information helps to understand the concerns and interests of the second group, while developing affective ties that reduce feelings of threat and refute negative stereotypes about members of the second group (Himmelroos \& Leino, 2016). It could also be an explanation of the more negative opinions on immigrants among Slovak and Czech Republic - the less possible contact with immigrant, the more prejudice, stereotypes and negative opinions. These assumptions should be verified empirically.

The cross-sectional character of the available data limits the research. The contribution of the paper is an overview of the opinions of V4 countries on a representative sample, thanks to which it is easier to understand the mood in the countries on this always-topical issue. 


\section{References}

Allport, G. W. (1954). The nature of prejudice. Reading, MA: Addison Wesley.

Bansak, K., Hainmueller, J., \& Hangartner, D. (2016). How economic, humanitarian, and religious concerns shape European attitudes toward asylum seekers. Science. 354 (6309): 217 - 222. doi: $10.1126 /$ science.aag2 147

Boelhouwer, J., Kraaykamp, G., \& Stoop, I. (2016). Trust, life satisfaction and opinions on immigration in 15 European countries. The Netherlands Institute for Social Research.

Ellison, C. G., Shin, H., \& Leal, D. L. (2011). The contact hypothesis and attitudes toward Latinos in the United States. Social Science Quarterly, 92, 938-958.

Eurobarometer 88.2:European Commission, Brussels. (2018). TNS opinion, Brussels [producer]. GESIS Data Archive, Cologne. ZA6927 DatafileVersion 1.0.0, DOI:10.4232/1.13005

Gravelle, T. B. (2016). Party identification, contact, contexts, and public attitudes toward illegal immigration. Public Opinion Quarterly, 80, 1-25.

Hainmueller, J., \& Hangartner, D. (2013). "Who Gets a Swiss Passport? A Natural Experiment in Immigrant Discrimination.”American Political Science Review, 107(1):159-187. doi: $10.1017 / \mathrm{S} 0003055412000494$

Heath, A., \& Richards, L. (2016). Attitudes towards Immigration and their Antecedents: Topline Results from Round 7 of the European Social Survey. Retrieved 2.7.2019. Available online: http://www.europeansocialsurvey.org/docs/findings/ESS7_toplines_issue_7_immigration.pdf

Heath, A., Schmidt, P., Green, E., Ramos, A., \& Davidov, E.. (20̄14). Attitudes Towards Immigration and their Antecedents: Module Proposal (repeat) for Round 7 of the European Social Survey.

Helbling, M., \& Kriesi H. (2014). "Why Citizens Prefer High- over Low-Skilled Immigrants: Labour Market Competition, Welfare State, and Deservingness."European Sociological Review, 30(5): 595-614. doi: 10.1093/esr/jcu061

Himelroos, S., \& Leino, M. (2016). Attitudes toward immigration and the neighborhood effect. Siirtolaisuus / Siirtolaisuusinstituutti = Migration / Institute of Migration, 43(3):49-52

Ho, A. K., Sidanius, J., Kteily, N., Sheehy-Skeffington, J., Pratto, F., Henkel, K. E., \& Stewart, A. L. (2015). The nature of social dominance orientation: Theorizing and measuring preferences for intergroup inequality using the new $\mathrm{SDO}_{7}$ scale. Journal of Personality and Social Psychology, 109(6), 1003 - 1028. DOI: http://dx.doi.org/10.1037/pspi0000033

Hopkins, D. J. (2015). "The Upside of Accents: Language, Inter-group Difference, and Attitudes Toward Immigration." British Journal of Political Science ,45(3): 531-557. doi: $10.1017 / \mathrm{S} 0007123413000483$

IOM. (2019). Migrácia na Slovensku. Medzinárodná organizácia pre migráciu. Retrived 10.11.2019. Available online: https://iom.sk/sk/migracia/migracia-na-slovensku.html

Karreth, J., Singh, S. P., \& Stojek, S. M. (2015). Explaining attitudes toward immigration: The role of regional context and individual predispositions. West European Politics, 38, 1174-1202.

Kucharczyk, J., Lada, A., \& Scholer, G. (2017). Exit, voide or loyalty? Young people on Europe and Democracy. Warsaw: Instute of Public Affairs.

Nshom, E., \& Croucher, S. (2017). Perceived threat and prejudice towards immigrants in Finland: A study among early, middle, and late Finnish adolescents, Journal of International and Intercultural Communication, DOI: 10.1080/17513057.2017.1312489

Parrillo, V. N., \& Donoghue, C. (2005). Updating the Bogardus social distance studies: A new national survey. Social Science Journal, 42, 257-271.

Roccato, M., \& Ricolfi, L. (2005). On the correlation between rightwing authoritarianism and social dominance orientation. Basic and Applied Social Psychology, 27, 187-200.

Schlueter, E., \& Scheepers, P. (2010). The relationship between outgroup size and anti-outgroup attitudes: A theoretical synthesis and empirical test of group threat-and intergroup contact theory. Social Science Research, 39(2), 285-295.

V4 report, (2019). Asylum Seekers and Beneficiaries of International Protection in V4 Countries (Updated Report) Available online: https://www.clovekvtisni.cz/media/publications/1221/file/cr_v4niem_2019.pdf

Vašečka, M. (2009). Postoje verejnosti k cudzincom a zahraničnej migrácii v Slovenskej republike, Medzinárodná organizácia pre migráciu.

Verkuyten M., Mepham, K. \& Kros, M. (2018). Public attitudes towards support for migrants: the importance of perceived voluntary and involuntary migration, Ethnic and Racial Studies, 41(5), 901-918, doi: 10.1080/01419870.2017.1367021 